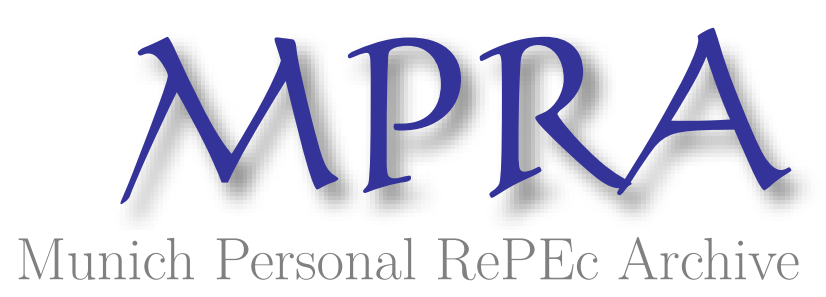

\title{
Economic Valuation of a Wetland in West Bengal, India
}

Mukherjee, Sacchidananda

International Water Management Institute (IWMI)-TATA Water Policy Research Programme

3 April 2008

Online at https://mpra.ub.uni-muenchen.de/14365/

MPRA Paper No. 14365, posted 01 Apr 2009 04:32 UTC 


\title{
ECONOMIC VALUATION OF A WETLAND IN WEST BENGAL, INDIA
}

\author{
Sacchidananda Mukherjee ${ }^{1}$
}

\begin{abstract}
In the Gangetic flood plain of West Bengal, wetlands are used for multiple purposes, and have significant role in the livelihoods of the local people. Over the years, these Multiple Use Systems (MUSs) are getting converted to single use systems due to economic and social pressure from dominant stakeholders, which are higher than that in single use systems. Economic and ecological functions of MUS changes over time and space. These dynamic aspects of MUS are often not fully appreciated. Attempts to classify wetlands according to their uses across ecological zones and to do their economic valuation are very limited.

Based on available secondary information, a wetland was selected in Bardhaman district of West Bengal to evaluate the economic benefits from multiple uses namely, wetland cultivation, irrigation, fisheries, jute retting, and fodder collection. The study shows that the major economic benefits that people living in the surrounding area of wetland derive are from wetland cultivation; direct irrigation; jute retting; and fisheries. The most important benefit was from fisheries, followed by wetland cultivation and jute retting. The irrigation benefits were found to be low due to larger distance of the land from the wetland, and the easy access to shallow groundwater in the region. However, the many ecological functions of the wetlands are not evaluated in the study.
\end{abstract}

\section{INTRODUCTION}

Water systems are used for various purposes. However, except for one or two uses, most uses might be non-consumptive in nature. Supplementary uses, which are consumptive in nature, may compete with the dominant uses. Hence, decision making with regard to allocating wetlands for various uses might involve trade offs. Hence, understanding the nature of trade offs is important for better decision making in water management (Dugan et al., 2006).

In India, wetlands are classified according to their location (coastal or inland), water quality (saline or freshwater), physiognomy (herbaceous or woody), duration of flooding (permanent or seasonal) etc. However, the uses and their economic aspects are missing from the present classification system (Gopal and Sah, 1995). The classification of wetlands according to their major and minor uses (both consumptive and non-consumptive), and quantifying the benefits from them in economic terms is crucial for identifying conservation interventions and improving their performance. As Renwick (2001) argues, accounting for economic value of all uses of water within a multiple use system is essential for informed decision making for productive, equitable and sustainable water uses.

But, uses of wetlands are dynamic. The type of use varies with space, i.e., across different ecological zones. For example, wetlands in the Gangetic floodplain of West Bengal mostly use for irrigation (e.g., Bardhaman and Nadia district), whereas costal wetlands are mostly use for shrimp culture because of sea water interface (e.g., South 24-Parganas and Medinipur district of West Bengal). The wetland uses also change across years depending on the interest of the dominant stakeholders, and the social pressures. For example, a tank, which is predominantly used for irrigation in a normal rainfall year, might be used for fisheries purpose as well in a very wet year when the tank inflows become large. Similarly, in a bad year, the same tank might get used for tank bed cultivation when the inflows are insignificant. Therefore, in order to have a comprehensive understanding, evaluation of wetlands should cover different ecological setting and typical years, i.e., wet, dry and normal.

${ }^{1}$ Senior Scientific Officer, International Water Management Institute (IWMI), C/o, ICRSAT, Patancheru, Andhra Pradesh-502 324, India. Email: sachs.mse@gmail.com 
Further, the existing property right regimes are important for proper management of MUS. As Datta and Roy Choudhary (1999) argue, ownership pattern of the wetland (e.g., common property resource, private property - single owner or multiple owner, and public property) greatly influence economic and ecological performance of the wetland. Therefore, it is also very important to evaluate the performance of the MUS under different property rights regime

There are some studies available on multiple purposes. For example, Q. Li et al. (2005) carried out a study for the Lower Bhavani Project canal in Tamil Nadu, Boelee et al. (2007) carried out case studies for irrigation systems in Africa and South Asia. Gowing et al. (2004) argued that auxiliary storage reservoirs could improve the efficiency of Mahaweli System in Sri Lanka through improving service delivery and recovering return flows, it could also provide an opportunity to use the reservoirs as MUS. Meinzen-Dick and Bakker (1999) argued that accommodation of stakeholders in participatory management of water system is important to enhance the productivity of the system. Instead of single use system, multiple use systems generate large benefits to the society and it is accrued to different groups of people. Studies analyzing economic and ecological value of wetlands exist in India and elsewhere. However, valuation of wetland, which performs as multiple use systems, is rare.

\subsection{Economic Valuation of Wetland as Multiple Use System in India}

Economic valuation of wetland has been carried out in different parts of India. Researchers have attempted to capture both use and non-use values of wetlands. Verma (2001) estimated economic value of Bhoj wetland (having water spread area of 32.29 square kilometer) for mainly direct uses. Das et al. (2002) estimated the economic value of ten wetlands in the Gangetic flood plain in Bardhaman district of West Bengal. The area of the wetlands varies from 10 ha to 275 ha with an average area of 66 ha. The estimated economic benefit from fisheries operation varies from Rs. 500 to Rs. 16,000 per ha per year; average irrigation benefit is Rs. 3.543 with a maximum of Rs. 16,000; average benefit of using wetland for jute retting is Rs. 200 per ha per year with a maximum of Rs. 625 per ha per year. Average benefit from fisheries operation varies from Rs. 2,484 per household, irrigation benefit - Rs. 1,105 per acre and jute retting Rs. 483 per household per year.

Chattopadhyay et al. (2002) estimated the potential losses due to conversion of 1500 ha of East Calcutta Wetlands in the year of 1999-2000 as Rs. 338.90 million. The willingness to pay of the stakeholders to conserve the East Calcutta Wetland, the amount varies from Rs. 60/per household/year to Rs. 1200/per household/year, with an average of Rs. 380/per household/year.

\section{OBJECTIVES}

The maim objective of this study is to assess the economic value of various functions of a multiple use wet land in West Bengal, excluding those which are ecological in nature.

\section{DESCRIPTION OF THE STUDY LOCATION}

The present study focused on economic valuation of wetland as MUS in a perennial fresh water wetland in West Bengal. Though, Bhattacharya et al. (2000) and ISRO, IWMED and NATMO (2003) identified wetlands in West Bengal, it is difficult to identify the wetlands according to their uses. Based on the ecological condition and pressure from economic activities, wetlands in different areas are used for different purposes. Therefore it is difficult to identify wetlands which are used as MUS. The selection of a multiple use water system is based on the study conducted by Das et al. (2002) among ten wetlands in Bardhaman district of West Bengal. Based on available information on different functions and uses of wetlands among ten wetlands, we have selected a single wetland for our case study. Their corresponding returns for a private wetland in West Bengal State of India.

\footnotetext{
${ }^{2}$ Beel (or Bheel) is a natural lake, generally an oxbow in Assam and West Bengal (Gopal and Sah, 1995). It is a U-shaped lake water body formed when a wide meander from the mainstream of a river is cut off to create a lake. Source: http://en.wikipedia.org/wiki/ Oxbow_lake).
} 
Kalobaur beel is an oxbow lake located in Dainhat municipality of Bardhaman district of West Bengal. ${ }^{2}$ Mean depth of water of the beel varies from 3.36 meter in pre-monsoon to 8.39 in post-monsoon and the water spread area of the beel is 32 ha in pre-monsoon and 38 ha in post-monsoon. According to 2001 Population Census, Dainhat municipality has 4,526 households with a total population of 22,593. However, the beel is located in Ward No. 2 and 10 of Dainhat municipality. Four habitations viz., Natunpara, Gopalganj, Vhaosingh para and Char Dainhat surround the beel. It is in the East side of the Dainhat railway station and almost 3 Kilometer away from the station. The beel is in the right side of the Hoogly River and within one kilometer of the river. Hydrology of the beel gets influenced by the Hoogly River, and gets water from the river through lateral seepage.

The area of Kalobaur beel is approximately 40 ha which is currently under the ownership of 45 households. Our filed visit revealed that the local municipality wanted to procure the Kalobaur beel and the adjacent land from the owners and farmers to conserve the beel for livelihoods development. However, owners of the wetland are not willing to hand over the beel to the municipality.

After the construction of Farakka Barrage, the wetland got a fresh life. Now, most parts of the year beel gets water. Since the whole area is under the Gangetic flood plain, it gets flooded during rainy season and remains waterlogged for three to four months (June - July to September - October). After construction of Farkka barrage, siltation rate in the Hoogly River has gone up which results in recurrent flood in the Gangetic Flood plain of West Bengal. Deposition of silt during rainy season make the land in the flood plain highly fertile and farmers could cultivate only two crops instead of tree crops in other parts of West Bengal. Jute is the main crop cultivated during water logged periods, as it can with withstand standing water and requires standing water for retting. The Kalobaur beel is a multiple use system, where apart from fisheries (both indigenous and cultured), the wetland bed itself is used for cultivation of boro paddy and jute. The wetland water is also used for irrigation and jute retting and farmers collect fodder from wetland. The farmers told that they find cultivation of paddy in the wetland is remunerative as they could save money in terms of labour, irrigation and fertilizers costs.

Das et al. (2002) estimated number of beneficiaries and benefits derived from different uses of the Kalobaur Beel. Culture fishery is the major activity and 200 households derive total benefit of Rs.144000/year. Next is the irrigation benefit where 100 farm-households derive total benefit of Rs. 70,000/year. Another 60 households derive benefits from jute retting where total benefit is Rs. 20,000/Year.

\section{METHODOLOGY AND DATA SOURCES}

\subsection{Methodology of Economic Valuation}

There are six major direct economic functions of the wetland, viz., use for cultivation; use of wetland as a source of irrigation; wetland fisheries; use of wetland water for domestic uses; and jute retting and as a source of fodder. The economic value of wetland cultivation was evaluated by taking the incremental benefit from wetland cultivation over upland cultivation and the rental value of land used for wetland cultivation. The economic value of irrigation benefit from wetland was assessed by taking the differential cost/opportunity cost of irrigation from alternative sources and the total area irrigate from the wetland and the opportunity benefit of using wetland water.

Economic value of fisheries in the wetland was evaluated by considering the two management patterns: a) owners operated, i.e., when wetlands owners carry out the fisheries operation; and, b) lease holders operated, i.e., when fisheries operation is leased out to private operators. Both costs and benefits aspects were considered for the estimation of economic value of fisheries operation in the wetland. The economic benefit of using wetland for various domestic uses was evaluated by considering the costs of substitution and benefits of convenience approach. Fodder collection benefit from wetland was evaluated by considering the cost of buying equivalent amount of fodder from the village. However, this is applicable to only those who do not have land, or do not cultivate crops such as wheat and paddy whose byproducts can be used as fodder. 


\subsection{Sampling Procedure}

A random sampling procedure was followed to select sample households on the basis of the discussion of local people and discussion with the local field assistants. Voluntary participations of the respondents were sought based on their availability of time and interest on the subject of our research. A pre structured questionnaire survey has been administered among 55 farm-households spread across eight habitations surrounding the wetland. The survey has been conducted during January 2008 with the help of five qualified field assistants and three local guides. A brief description of the scope and coverage of the study and possible outcomes of the study was provided before starting face-to-face interviews with the head of the household. Apart from household questionnaire survey various secondary information were collected from the local people, fertilizer shop and local political leaders.

\subsubsection{Sampling Criteria}

Since stratification of the sample households on the basis of their land holding size and dependence on the Kalobaur beel was difficult due to paucity of secondary level information. We have followed selected sample households having land in the beel or use the wetland bed to cultivate crops or use wetland water to irrigate croplands.

\subsubsection{Profile of the Respondents}

Age of the respondents varies from 15 years to 69 years with an average age of 45 years. Out of 55 respondents, thirteen of the respondents (i.e., 23.6\%) were young ( $₫ 35$ years), another 30 respondents $(54.5 \%$ ) were middle aged (36 - 55 years) and 12 respondents $(21.8 \%)$ were old having age greater than 55 years. Education level of the respondents varies from zero to 17 years, with an average year of education of 8 years (Table 1). Family size of the respondents varies from 2 to 15 , with an average of 6 . Our sample covers a total of 332 population of which $55 \%$ male and $45 \%$ female, children (below 15 years of age) constitutes $21 \%$ of our sample population. Mean family workforce participation rate for our sample households is $45.5 \%$ as compared to $75 \%$ for male. In our sample population $65.5 \%$ of adult male population is economically active as compared to $39.2 \%$ of their female counterpart (in Table 2). Forty seven\% of respondents were Schedule Caste, $35 \%$ Other Backward Caste (OBC) and another $18 \%$ were open category.

Table 1 shows that the sample households hold 44.7 ha of land, of which 18.7 ha is under wetland and 26.0 ha is under upland cultivation. Average size of wetland holding is 0.41 ha which varies from 0.04 to 2.31 ha, and for upland average size of land mean holding is 0.65 ha with a minimum of 0.12 ha and maximum of 3.35 ha. For all together mean land holding is 1.01 ha which varies from 0.23 to 4.86 ha. Majority of the farmers are marginal and small farmers having land up to 1 ha. Both number of holdings and area under operation show similar pattern.

\section{RESULTS AND DISCUSSION}

\subsection{Benefits from Wetland Cultivation}

0During monsoon the area surrounding the Kalobaur beel gets water logged and except jute it is difficult for farmers to cultivate other crops during the monsoon. Jute is the only crop which could withstand the standing water as a result jute is cultivated both in upland surrounding the wetland and the wetland bed. As water recedes from the land surrounding the beel, farmers start cultivation by spreading the deposited silt uniformly through ploughing and taking out extra water from the land. Upland farmers surrounding the beel generally get two crops per year and farmers having land in the water spread area of the beel gets single crop. Boro paddy is the major crop cultivated in the water spread area of the beel, where the process of cultivation starts at the end of November in every year. Farmers found wetland cultivation is remunerative as they could save money in 
terms of fertilizer costs and labour costs in terms of less time spent on irrigation. Apart from the nutrient enriched silt of the wetland, wetland water has high nutrient value as a result farmers are expected fetch higher yield for wetland paddy as compared to upland paddy. Farmlands surrounding the beel are irrigated mostly from the beel and it helps the farmers to cut down their costs on fertilizers as nutrient of wetland water is higher than the fresh water from ground and/or river.

During summer season when wetland bed dries up, wetland cultivation is a common practice carried out by the farmers having land in wetland bed and/or in the low lying area. According to our sample survey total area under wetland cultivation is 30 acre. Paddy and jute are the major crops cultivated in the wetland bed. 55\% of our sample households cultivate wetland paddy with an average size of land holding is 0.6 acre and another $18 \%$ of our sample households cultivate jute in the wetland bed with an average size of land holding is 0.9 acre. Total area under wetland paddy cultivation is 18 acre and jute is 9 acre. According to discussion with the stakeholders, 70 households practice wetland cultivation. If the wetland cultivators cultivate the wetland for paddy and jute only, then total area under wetland paddy cultivation is estimated to be 25 acre and jute cultivation is 13 acre. The benefits from an acre of cultivation of paddy and jute are provided in the Table 3 . The estimated benefit from wetland cultivation is Rs. 3.59 lac per year.

Table 1: Land Holding Pattern of the Sample Households

\begin{tabular}{|c|c|c|c|c|c|c|c|}
\hline \multirow[b]{2}{*}{ Land } & \multirow[b]{2}{*}{$\begin{array}{l}\text { Holding } \\
\text { category }\end{array}$} & \multicolumn{2}{|c|}{ Wetland Holding } & \multicolumn{2}{|c|}{ Upland Holding } & \multicolumn{2}{|c|}{$\begin{array}{c}\text { Wetland and Upland } \\
\text { Holding }\end{array}$} \\
\hline & & Number & $\begin{array}{l}\text { Area } \\
\text { (in ha) } \\
\end{array}$ & Number & $\begin{array}{l}\text { Area } \\
\text { (in ha) }\end{array}$ & Number & $\begin{array}{c}\text { Area } \\
\text { (in ha) }\end{array}$ \\
\hline Sub-marginal & $(<0.5 \mathrm{ha})$ & $42 \quad(76)$ & $6.1 \quad(33)$ & $36 \quad(65)$ & $6.3 \quad(24)$ & $23 \quad(42)$ & $7 \quad(16)$ \\
\hline Marginal & $(0.5-1.0 \mathrm{ha})$ & $8 \quad(15)$ & $5.2 \quad(28)$ & $11 \quad(20)$ & $7.7 \quad(30)$ & $14 \quad(25)$ & $9.5 \quad(21)$ \\
\hline Small & $(1.0-2.0 \mathrm{ha})$ & $4 \quad(7)$ & $5.1 \quad(27)$ & $7 \quad(13)$ & $8.7 \quad(33)$ & $16 \quad(29)$ & $21 \quad(47)$ \\
\hline Semi - medium & $(2.0-4.0 \mathrm{ha})$ & $1 \quad(2)$ & $2.3 \quad(12)$ & (2) & $3.4 \quad(13)$ & (2) & $2.3 \quad(5)$ \\
\hline Medium & $(4.0-10.0 \mathrm{ha})$ & -- & -- & -- & -- & (2) & $4.9 \quad(11)$ \\
\hline Total & & $55 \quad(100)$ & $18.7 \quad(100)$ & $55 \quad(100)$ & $26.0 \quad(100)$ & $55 \quad(100)$ & $44.7 \quad(100)$ \\
\hline
\end{tabular}

Note: Figure in the parenthesis shows the percentage of total number of observation and total land holding of the sample households.

Source: Primary Survey

\subsection{Benefits from Using Wetland as a Source of Irrigation}

Cost of irrigation from wetland is cheaper for upland paddy cultivation as compared to irrigation from wetland. The cost of irrigation from wetland mostly depends on the distance between wetland and farmland, which varies across farmlands from minimum 200 feet to maximum 6,562 feet with an average distance of 2,436 feet. However, costs of irrigation for farmers using both groundwater and wetland water is comparatively lower. Since the pricing of canal and river water is not volumetric basis, the cost of irrigation is cheaper. ${ }^{3}$ In the Gangetic flood plain groundwater depth is low and it varies from 50 to 200 feet across our sample farmlands with an average of 137 feet. A different picture emerges for upland jute cultivation. The cost of irrigation from wetland is higher as compared to groundwater. Average depth of groundwater is lower for farmlands where jute is cultivated i.e., 75 feet. For jute nutrient benefit of using wetland water for irrigation is distinct as compared to paddy cultivation.

\footnotetext{
${ }^{3}$ Cost of using canal and river water for irrigation is Rs. 800/bigha/year. Farmlands in this area mostly cultivated twice, therefore cost of irrigation from canal or river water is Rs. 400/bigha/ season.
} 
Table 2: Number of Beneficiaries according to Use of Wetland

\begin{tabular}{|l|c|}
\hline \multicolumn{1}{|c|}{ Different Uses of Wetland } & $\begin{array}{c}\text { Beneficiaries } \\
\text { (No of Households.) }\end{array}$ \\
\hline a) Wetland cultivation (No. of Hhs.): & 70 \\
\hline b) Wetland fisheries (No. of Hhs.): & 66 \\
\hline c) Irrigation from Wetland (No. of Hhs.): & 50 \\
\hline d) Jute retting (No. of Hhs.): & 250 \\
\hline e) Duck keeping (No. of Hhs.): & 25 \\
\hline f) Fodder collection (No. of Hhs.): & 150 \\
\hline g) Cattle grazing cattle (No. of Hhs.): & 150 \\
\hline i) Collection of small fishes, snails (Samuk, Googli etc.) \\
and amaranthus (Kalmi, Hincha, Saluk etc.) (No. of Hhs.):
\end{tabular}

Apart from wetland cultivation, according to our sample survey 36.6 acre (Kharif: 19 acre; Rabi: 16.5 acre and Boro: 1.1 acre) of upland is irrigated from the Kalobaur beel. The farmers irrigating farmlands from wetland do not have to pay any fees or royalty to the owners of the wetland. Pumping groundwater from shallow bore wells fitted with pump set having capacity of 5 Horsepower is also common during dry season. The cost of pumping water from the wetland depends on the distance between wetland and the farmland. Mostly diesel pump set having capacity of 5 horsepower is used to pump water from wetland to irrigate upland surrounding the beel. Farms adjacent to the beel also use manual lifting devices. Average cost of pumping water from the wetland is estimated based on the number of times a farmland is irrigated and average hour of irrigation. Average cost of taking a pump set in rent is Rs. 50/hour and average diesel consumption is 1 litre per hour. There at Rs. 35/litre of diesel price, the cost of pumping water per hour is Rs. 85. Apart from paddy and jute, cucumber, mustard seeds, wheat, and other vegetables are cultivated in the wetland bed and also in peripheral areas of the wetland. Farmers told that they find irrigation from wetland is remunerative as they could save money in terms of fertilizers costs.

To estimate the nutrient benefit of using wetland water for irrigation, we estimated fertilizer cost associated source(s) of irrigation. The difference in the costs is taken as benefit of using wetland water for irrigation. Average benefit of using wetland water over groundwater for upland paddy cultivation is Rs.555/acre/season

Table 3: Economic Benefit of Wetland Cultivation

\begin{tabular}{|l|r|c|}
\hline Sources of Benefits and Costs & Paddy & Jute \\
\hline Average Net Benefit from Wetland Cultivation (in Rs./acre/season) & 12,834 & 40,812 \\
\hline Average Net Benefit from Upland Cultivation (in Rs./acre/season) & 7,143 & 37,068 \\
\hline Incremental Benefit from Wetland Cultivation (in Rs./acre/season) & 5,691 & 3,744 \\
\hline Cost of Hiring Upland (in Rs./acre/season)* & 4,375 & 4,375 \\
\hline Total Benefit of Wetland Cultivation (in Rs./acre/season) & 10,066 & 8,119 \\
\hline Area under Wetland Cultivation (in acre) & 25 & 13 \\
\hline Net benefit from Wetland Cultivation (in Rs./acre/season) & $2,51,650$ & $1,05,547$ \\
\hline
\end{tabular}

Note: *-prevailing land rent payable to lease in upland is Rs. 2500/bigha/year and wetland is Rs. 1000/bigha/ year. In case of upland it is used for two crops and wetland it is for single crop $(3.5$ bigha $=1$ acre $)$ 
Table 4: Benefit of Wetland Paddy Cultivation

\begin{tabular}{|c|c|c|c|c|c|c|}
\hline & \multicolumn{3}{|c|}{ Wetland Paddy Cultivation } & \multicolumn{3}{|c|}{ Upland Paddy Cultivation } \\
\hline & Mean & Minimum & Maximum & Mean & Minimum & Maximum \\
\hline Seed Cost (in Rs./acre) & 839 & $350 \quad(9)$ & $1960 \quad(13$ & $614 \quad(4)$ & $368 \quad(8)$ & $980 \quad(3)$ \\
\hline Labour Charges (in Rs./acre) & 4950 & $2800 \quad(71)$ & $7700 \quad(51)$ & $4,325 \quad(30)$ & $1,750(39)$ & $10,500(29)$ \\
\hline Cost of Irrigation (in Rs./acre) & & & & $6,157 \quad(43)$ & $1,400(31)$ & $17,850(49)$ \\
\hline \multicolumn{7}{|l|}{ Cost of Hiring / Using Farm } \\
\hline Machineries Cost (in Rs./acre) & 1519 & $560 \quad(14)$ & $2450 \quad(16)$ & $1,594 \quad(11)$ & $735(16)$ & $3,500(10)$ \\
\hline \multicolumn{7}{|l|}{ Fertilizer \& Pesticide Cost } \\
\hline (in Rs./acre) & 1075 & $224 \quad(6)$ & $3136 \quad(21)$ & $1,545 \quad(11)$ & 263 & $3,500(10)$ \\
\hline Total Cost (Rs./acre) & 8,383 & 3,934 & 15,246 & 14,235 & 4,515 & 36,330 \\
\hline Yield (in Quintal/acre) & 29.3 & 22.4 & 35.0 & 28.5 & 19.6 & 42.0 \\
\hline Market Price (Rs./quintal) & 724 & 500 & 1000 & 751 & 583 & 1,250 \\
\hline Gross Revenue (Rs./acre) & 21,216 & 11,200 & 35,000 & 21,377 & 11,433 & 52,500 \\
\hline Net Revenue (Rs./acre) & $12,834 \quad 7,266$ & 19,754 & 7,143 & 6,918 & 16,170 & \\
\hline
\end{tabular}

Note: Figure in the parenthesis shows the percentage of total cost

*-implies that for wetland paddy cultivation cot of irrigation is included in labour charges and machinery hiring/using costs.

Source: Primary Survey

Table 5: Benefit from Wetland Jute Cultivation

\begin{tabular}{|c|c|c|c|c|c|c|}
\hline \multirow[b]{3}{*}{ Seed Cost (in Rs./acre) } & \multicolumn{3}{|c|}{ Wetland Jute Cultivation } & \multicolumn{3}{|c|}{ Upland Jute Cultivation } \\
\hline & Mean & Minimum & Maximum & Mean & Minimum & Maximum \\
\hline & $247 \quad(3)$ & 105 & 350 & 198 & $105 \quad(3)$ & $300 \quad(2)$ \\
\hline Labour Charges (in Rs./acre) & $3,981 \quad(44)$ & $2,800 \quad(50)$ & $5,950 \quad(45)$ & $4,788 \quad(47)$ & $1,703(48)$ & $8,225(42)$ \\
\hline Cost of irrigation (in Rs./acre) & $2,532 \quad(28)$ & $1,260 \quad(23)$ & $3,360 \quad(25)$ & $2,863 \quad(28)$ & $893(25)$ & $4,970(25)$ \\
\hline $\begin{array}{l}\text { Fertilizer \& Pesticide Cost } \\
\text { (in Rs./bigha) }\end{array}$ & $1,042 \quad(11)$ & $723 \quad(13)$ & $1,750 \quad(13)$ & $1,113 \quad(11)$ & $525(15)$ & $3,342(17)$ \\
\hline $\begin{array}{l}\text { Machine Hiring / Using Cost } \\
\text { (in Rs./acre) }\end{array}$ & 1,305 & $700 \quad(13)$ & 1,890 & $1,322 \quad(13)$ & $350(10)$ & $2,800(14)$ \\
\hline Yield (in Quintal/acre) & 14 & 14 & 14 & 13 & 7 & 19 \\
\hline Market Price (Rs./Quintal) & 3,566 & 3,150 & 4,375 & 3,721 & 2,800 & 5,250 \\
\hline Total Cost (Rs./acre) & 9,107 & 5,588 & 13,300 & 10,283 & 3,575 & 19,637 \\
\hline Total Revenue (Rs./acre) & 49,919 & 44,100 & 61,250 & 47,351 & 19,600 & 01,063 \\
\hline Profit (Rs./acre) & 40,812 & 38,512 & 47,950 & 37,068 & 16,025 & 81,425 \\
\hline
\end{tabular}

Note: Figure in the parenthesis shows the percentage of total cost Source: Primary Survey

and for jute it is Rs. 184/acre/season. If the entire wetland irrigated area is cultivated with paddy, the annual benefit of wetland irrigation is estimated to be Rs. 20,313/year. And if the entire is cultivated with jute the benefit of using wetland water for irrigation is estimated to be Rs. 6,734/year. 


\subsection{Benefits from Fisheries Operation}

Previously owners used to lease out the wetland for fisheries operation for the period - June-July to October-November. Mostly local people individually or collectively used to bid for the wetland. The last time it was leased out for three years at an amount of Rs. 5 lac. The owners used to make benefit by leasing out the wetland, however during those years they used to deprive of getting fish for their own consumption. After the commercial fisheries, the owners used to cultivate boro paddy in the same wetland bed (November-December to May-June) and farmers from surrounding farmlands used to lift water from wetland for irrigation. The preparation of nursery bed and land used to start during November and transplantation work used to start during December. However, due to construction of Farakka Barrage, the beel gets water for more months and as a result the process gets delayed. Over the years the siltation in the Hoogly River bed has also reduced its water holding and carrying capacity. As a result frequent flood and land subsidence is occurred in the Gangetic flood plain of West Bengal (Prof. Kalyan Rudra, Personal Communication). However, currently the owners themselves are operating the fisheries through the formation of a committee. The committee consisting of 15 members from owners households, of which 5 members are directly involved with the fishing and various operational aspects of the wetland, and another 10 member is involved with security of the beel, as there is continuous threat of fish lifting from wetland by non owners community. The people involved in the protection, fisheries operation and management are paid from the committee depending on their time of involvement.

Economic value of fisheries operation in the wetland is evaluated by considering the two management patterns - a) owners operated - when wetland owners carry out fisheries operation by themselves, and b) lease holders operated - when wetland owners lease out the wetland to private operators for an amount decided by open bidding process. Under owners operated system, the wetland fisheries is managed by the formation of a committee where the costs of the fisheries operation is borne by the committee from previous year's income after paying the land revenue of Rs. 16,000/annum payable to the Dainhat Municipality. The owners get the monetary benefit according to their land holding in the wetland. On an average from each acre of wetland holding, owners get Rs. 4200/year from fishing alone. The total area under wetland fisheries is 80 acre. Therefore, total distribution of income from wetland is estimated to be Rs. 3,36,000/annum. The owner households involved with the protection, fisheries operation and management are also paid according to their contribution in terms of time spent. $22 \%$ of our sample farmers are involved with the various aspects of management of wetland, and average payment for their service is Rs. 2250/year. Therefore total payment is estimated to be Rs. $32,400 /$ year. Apart from the monetary benefits, owners also get fishes for their own consumption. On an

Table 6: Economic Benefits of Using Wetland Water for Irrigated Crops (in Rs./acre/season)

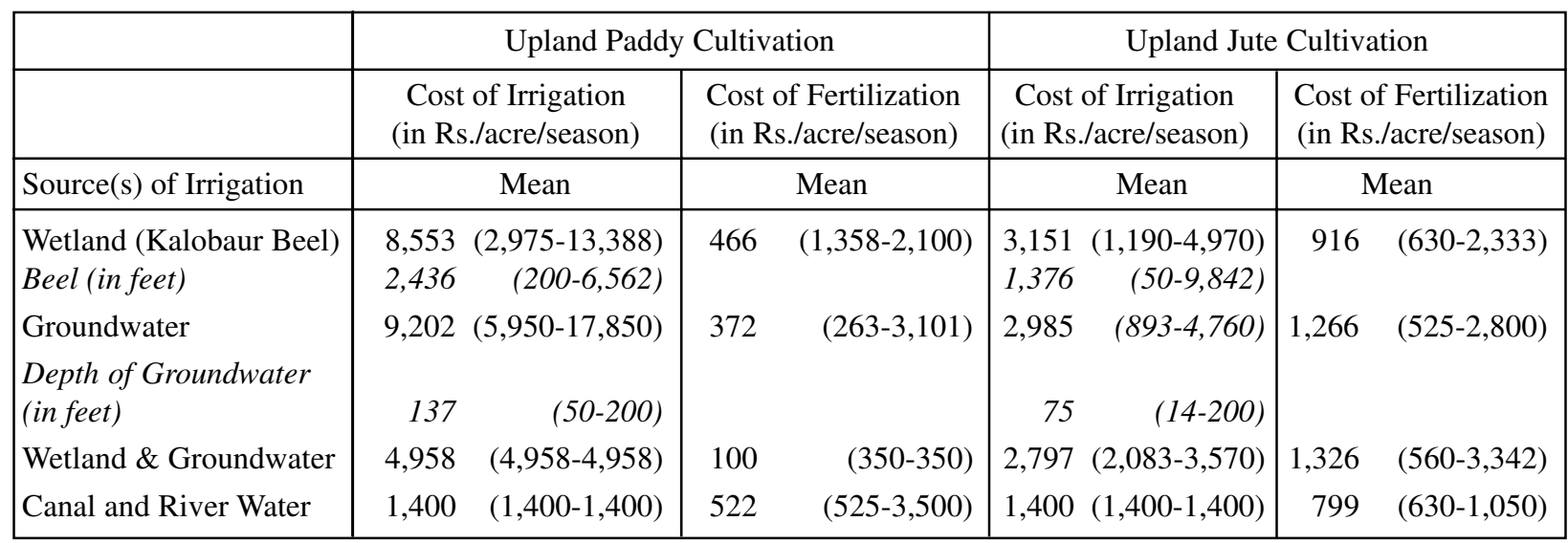

Note: Figures in the parenthesis show the range for the corresponding mean value 
average $53 \%$ of our sample get fish for their own consumption. It would have been cost of Rs. 375/household/ month to purchase the same amount of fish from the market. On an average $47 \%$ of our sample households collect small fishes and shellfishes from the wetland and the market price of their collection would have fetched Rs. 153/household/month.

\subsubsection{Non- owners' Benefits from Collection of Small Fishes and Shellfishes}

Collection of small fishes and shellfishes are not restricted to the owners only. A large number of people surrounding the wetland collect small fishes and shellfishes from the wetland. On an average 44\% of sample households collect small fishes and shellfishes from Kalobaur beel during rainy season. Yearly on an average 6 months (on an average) households collect those items which save on an average a cost of Rs. 317 per month per household and it varies from Rs. 120 to Rs. 900. In some instances, respondents revealed that people from lower strata of the society collects various shellfish and sell in local market at a remunerative price. Households were asked to reveal the amount that they have to pay to purchase those items that they collect from the wetland. The well defined market price made it easier for them to reveal the amount they save in each month through collection of various small fishes and shellfishes from wetland.

The total benefit from wetland fisheries is estimated to be Rs. 5,51,856 per annum. However, this is a conservative estimate as we do not take into account the costs of seeds, feeds etc. which is spent from previous year's savings. The estimation of beneficiaries of wetland is not exact. Therefore the estimate is in the lower side.

In 2002, the wetland was last leased out for an amount of Rs. 5 lac for 3 years. The lease holders fetched a profit of Rs. 3 lac. So, total income generation from wetland fisheries was Rs. 8 lac. Under lease holders operation, each of the 45 owner households could earn amount of Rs. 3703/year. However, the owners did not used to get any fish for their own consumption and even collection of small fishes was restricted. Due to costs involved to restrict the non-owners to access the wetland during night time is very high, stealing of fish by local people is a major cause of getting less benefit during owners operated regime. However, under owners operated system the owners meet their own consumption demand and the number of beneficiaries are large.

\subsection{Benefits from Jute Retting}

Jute (White Jute - Corchours capsularis and Tossa Jute - Corchorus olitorius) is the major commercial crop in the Gangetic flood plain of West Bengal. Availability of water bodies is an added advantage, which helps farmers in jute retting. During monsoon, the Kalobaur beel is used for jute retting by large number of farmers from surrounding habitations. Jute is a commercial crop, and jute sticks (pat kathi) mostly used for house walling, as bio-fuel, and for various religious purposes.

There are several methods of jute retting, e.g., chemical, biological, etc. however biological jute retting in water bodies mostly practiced due to cost efficiency. The study estimates the benefit of using wetland for jute retting. Traditionally farmers from the surrounding habitations are using the Kalobaur beel for jute retting and they do not have to make payment to the wetland owners for the wetland service. However, owners complained that jute retting is one of the main reasons for reducing Dissolved Oxygen in the water body which cause fish death. In the Gangetic flood plain of West Bengal due to availability of large number of water-bodies helps jute cultivation and jute is cultivated in a substantial part of area. There are several reasons for that - a) during rainy season the whole area get flooded with water from the Hoogly River and other than jute other crops cannot withstand the high water logged area. During flood the huge amount of silt is also deposited in agricultural land which acts as natural fertilizer for subsequent crops. Availability of large number of water-bodies is the major advantage for the farmers to go for jute cultivation. However, some farmers prefer to use their own pond (Doba) for jute retting. The diesel cost associated with the filling up of the private pond (Doba) is considered as the shadow cost of jute retting. It has been found that 25 litre of diesel is required to pump the water from wetland to fill the pond which could accommodate jute from 1 bigha of land. The cost associated with 25 litre of diesel 
Table 7: Benefits from Fisheries Operation in the Wetland

\begin{tabular}{|l|c|}
\hline Sources of Benefit and Cost of Wetland Fisheries & Amount (Rs./Year) \\
\hline Water Tax payable to Dainhat Municipality & 16,000 \\
\hline Payment for protection, fisheries operation and management & 32,400 \\
\hline Benefit distributed among wetland holders & $3,36,000$ \\
\hline Cost saved in terms of expenditure on fish consumption & $1,46,534$ \\
\hline Non-owners benefit from collection of small fishes and shellfishes etc. & 20,922 \\
\hline Total benefits from wetland fisheries & $5,51,856$ \\
\hline
\end{tabular}

Source: Primary Survey

in West Bengal comes out to be Rs. 875 (@Rs. 35/litre of diesel). Farmers' were also asked to reveal their willingness to pay for jute retting (in Rs. Per bigha of jute produce), which varies from Rs. 50 to Rs. 500 with an average of Rs. 267.

Approximately 150 households from habitations surrounding the Kalobaur beel use the wetland water for jute retting. According to our sample survey among 55 farm households, $64 \%$ cultivate jute during Kharif season in the upland area and another $18 \%$ of the households practice wetland jute cultivation. Average size of upland under jute cultivation is 1.1 acre and 0.9 acre under wetland cultivation. Therefore total area under jute cultivation is estimated to be 133 acre. Average benefit of using the beel for jute retting is Rs. 935 per acre of jute cultivation. Therefore total benefit of jute retting is Rs. 1.24lac per year.

\subsection{Benefits from Domestic Uses}

To estimate the benefits of using wetland for various domestic uses (e.g., bathing and washing), we have taken into consideration the cost of installing tube well either individually or collectively. The cost of installation varies with respect to the desired depth of the tube well. However, having a tube well or house connection of water supply considerably reduces the time required to commute to the wetland. The convenience of having house connection or tubewell has been captured through the opportunity cost of time spent on commuting wetland. Average yearly benefit from wetland has been estimated. The opportunity cost of time spent could be justified only of the cost saving of having tube well individually or collectively or having house connection is much higher.These costs could be shared by individually or collectively. In case of collective utilization, the costs could be shared among the beneficiaries.

Table 7 shows that the cost saving through the use of wetland for domestic uses is much lower than the opportunity cost of the time spent in accessing the wetlands. Perhaps, this is the reason why the local communities do not depend on these wetlands alone for domestic water needs, and instead try to have their own private hand pumps, or common hand pump provided by the local municipality.

\subsection{Benefits derived for Animal Husbandry}

\subsubsection{Fodder Collection}

On an average $29.1 \%$ of our sample households collect fodder from the wetland. Farmers collect water hyacinth (Eichornia crassipes) and various water borne vegetations and supplement fodder to reduce cost of feeding the cattle population. On an average four months in a year sample households collect fodder from the wetland. Farmers without having agricultural land and/or do not cultivate paddy/wheat mostly collect fodder from the beel throughout the year. We estimate the benefits of collection fodder from wetland by using the cost

${ }^{4}$ Jute retting is the process which softens the tissues and breaks the hard pectin bond between the bast \& Jute hurd (inner woody fiber stick) and the process permits the fibres to be separated (source: http://en.wikipedia.org/wiki/Jute_cultivation) 
saved in terms less requirement of straw (paddy/wheat) and mustard cake. ${ }^{5}$ In our household questionnaire survey it has been revealed that on an average each household could save Rs. 372/month, which varies from Rs. 20 to 600/month depending on the size of the herd size and family's dependence on wetland fodder. Since, the collection also involves labour time, households having own source of fodder mostly avoids collection from wetland. The total number of households benefit from fodder collection is 150, and the rate of benefit is Rs. 1488/year, therefore total benefit from fodder collection is Rs. 2.23 lac.

\subsubsection{Benefits from Grazing}

Grazing on wetland and surrounding areas of the beel is limited to one to two months in a year. Having steep slope in the edge of the wetland and depth of water is quite high, it becomes difficult for cattle population to access vegetation in the wetland. The depth of water level in the beel remain high for a large part of the year and having little space surrounding the beel the grazing on wetland is limited. During summer as water recedes, households allow their cattle to graze on wetland bed. Cost saving in terms of grazing in wetland has been estimated to to be Rs. 313 per household per month. The benefits vary across households, from minimum Rs. 120/month to Rs. 700/month depending on their herd size. 150 households surrounding the beel benefit from wetland grazing and their monthly benefit is estimated to be Rs. 313. Therefore, total benefit from wetland grazing is estimated to be Rs. $46,950 /$ year.

Table 8: Average Costs and Benefits of Using Wetland for Domestic Purposes

\begin{tabular}{|l|r|}
\hline \multicolumn{1}{|c|}{ Descriptions } & Mean \\
\hline Cost of installing a hand pump fitted with tube well (in Rs.) & 5,487 \\
\hline Annualized cost of capital (Rs./Year)* & 582 \\
\hline Annual O\&M cost of hand pump (Rs./Year) & 50 \\
\hline Annualised capital and O\&M cost of hand pump (in Rs./Year) & 632 \\
\hline Time spent to access wetland (in hour/day) & 0.74 \\
\hline Opportunity Cost of Time (in Rs./day) ** & 4.6 \\
\hline Yearly Opportunity Cost of Time (in Rs./Year) & 1,692 \\
\hline Number of families could share a single hand pump comfortably for domestic purposes (in No.) & 3.3 \\
\hline
\end{tabular}

Note: *- implies annualized cost capital has been estimated using $10 \%$ real rate of interest and 30 years in the amortization process

**-implies daily wage rate for agricultural labour (i.e., Rs. 50/head/8 hour) is used to calculate the opportunity cost of time.

\subsection{Benefits from Collection of Amaranthus}

Apart from small fishes and various shellfishes, $42 \%$ of the sample households collect various amaranthus (Kalmi - Ipomoea aquatica; Hincha, Sushni, etc.) from wetlands. The economic benefit varies from Rs. 10 to Rs. 100/household/month, with an average of Rs. 39. Our discussions with the local people revealed that 30 households surrounding the beel collect various leaf vegetables (amaranthus) through out the year and the estimated benefit is Rs. 5,897.

\subsection{Benefits from Duck Keeping}

Duck keeping is not a regular practice for habitations surrounding the beel and only $11 \%$ of our sample households have ducks with an average number of 4.5 birds (minimum 1 to maximum 7 ). Since ducks are not fed on commercial feed, it becomes difficult for households reveal their costs saving of using wetland to feed their ducks.

${ }^{5}$ Straw and mustard cake are the main commercial items fed to cattle population in rural areas. 


\section{CONCLUSIONS AND AREAS FOR FUTURE RESEARCH}

In the Gangetic flood plain of West Bengal wetlands are used as multiple system and have significant impacts on livelihoods of the local people. Over the years Multiple Use Systems (MUSs) are getting converted to single use systems due to economic and social pressure from dominant stakeholders, which are larger than that of single use systems. Economic and ecological functions of MUS changes over time and space. These dynamic aspects of MUS are often not fully appreciated. Attempts to classify wetlands according to their uses across ecological zones and to do their economic valuation are very limited.

We have undertaken study of one such wetland in the lower Gangetic basin in West Bengal. The study shows that the major economic benefits that people living in the surrounding area of wetland are from wetland cultivation; direct irrigation; jute retting; and fisheries. The most important benefit is from fisheries, followed by wetland cultivation and jute retting. The irrigation benefits were found to low due to larger distance of the land from the wetland, and the easy access to shallow groundwater in the region.

Besides the direct economic functions, there are many ecological functions that a wetland performs. They are: nutrient trapping and recycling; spawning and breeding ground for indigenous fish species; groundwater recharge and impacts on hydrology; runoff and soil erosion control, and flood mitigation; regulating microclimate on the area surrounding the wetland. They also have economic values. However, they are not evaluated in the present study. This could be taken up for future research. Further, such an evaluation needs to be undertaken at the level of river

\section{REFERENCES}

Bhattacharyya , S., K. Mukherjee and J.K. Garg (2000), Wetlands of West Bengal, Institute of Wetland Management and Ecological Design, Calcutta and Space Application Centre, Ahmedabad.

Boelee Eline, Hammou Laamrani and Wim van der Hoek (2007), Multiple use of irrigation water for improved health in dry regions of Africa and South Asia, Irrigation and Drainage, Vol. 56, No. 1, pp. 43 - 51.

Chattopadhyay, Kunal (2000), Environmental Conservation and Valuation of East Calcutta Wetlands, Final Report, Funded by Environmental Economics Research Committee, World Bank Aided India: Environmental Management Capacity Building Programme.

Das, T.K., B. Moitra, A. Raichaudhuri, T. Jash, S. Ghosh and A. Mukherjee (2000), Degradation of Water Bodies and Wetlands in West Bengal: Interaction with Economic Development, Final Report, Funded by Environmental Economics Research Committee, World Bank Aided India: Environmental Management Capacity Building" Programme.

Datta, Samar K. and Mukut Roy Choudhury (1999), Redefining Property Rights for Sustaining the Wetlands around Calcutta, Working Paper No. 99-05-02, May 1999, Indian Institute of Management, Ahmedabad.

Dugan, P., M.M. Dey and V.V. Sugunan (2006), Fisheries and water productivity in tropical river basins: Enhancing food security and livelihoods by managing water for fish, Agricultural Water Management, Vol. 80, No. 1-3, pp. 262-275.

Ghosh, S. K. (2004), Traditional Commercial Practices in Sustainable Development and Conservation of Man and Wetlands, Paper presented at the 3rd IUCN World Conservation Congress, Bangkok, Thailand, November 17-25, 2004.

Gopal, B. and M. Sah (1995), Inventory and Classification of Wetlands in India, Plant Ecology, Vol. 118, No. 12, pp. 39-48.

GOI (2007), Conservation of Wetlands in India: A Profile: Approach and Guidelines, Conservation Division - I, Ministry of Environment and Forests, Government of India, New Delhi. 
Gowing, J. W., Li QiongFang, T. Gunawardhana (2004), Multiple-use management in a large irrigation system: benefits of distributed secondary storage, Irrigation and Drainage Systems, Vol. 18, No. 1, pp. 57-71.

Institute of Wetland Management and Ecological Design (IWMED) (undated), Special Studies on Wetlands of West Bengal for the Development, Conservation and Maintenance of the Habitats of Waterfowls and Associated Bio-Diverse Elements, Funded by the Department of Forest, Government of West Bengal.

Meinzen-Dick, R. and M. Bakker (1999), Irrigation Systems as Multiple-use Commons: Water use in Kirindi Oya, Sri Lanka, Agriculture and Human Values, Vol. 16, No. 3, pp. 281-293.

Q. Li, Q. J.W. Gowing and C. Mayilswami (2005), Multiple-use management in a large irrigation system: an assessment of technical constraints to integrating aquaculture within irrigation canals, Irrigation and Drainage, Vol. 54, No. 1, pp. 31-42.

Renwick, M.E. (2001), Valuing Water in a Multiple-Use System - Irrigated Agriculture and Reservoir Fisheries, Irrigation and Drainage Systems, Vol. 15, No. 2, pp. 149-171.

Space Application Centre (ISRO), Institute of Wetland Management and Ecological Design (IWMED) and National Atlas \& Thematic Mapping Organisation (NATMO) (2003), Wetland Information System: West Bengal (WINSYS)", Sponsored by the Ministry of Environment and Forest, Government of India, New Delhi.

van Koppen, B., P. Moriarty and E. Boelee (2006), Multiple-use water services to advance the millennium development goals, Research Report 98. International Water Management Institute, Colombo, Sri Lanka. 